\title{
PETROGRAPHY AND GEOCHEMISTRY OF DYKES FROM THE NORTHERN BONFIM METAMORPHIC COMPLEX, MINAS GERAIS, BRAZIL
}

\author{
M.A.Carneiro ${ }^{1}$
}

The northern Bonfim Metamorphic Complex, located west of the Serra da Moeda and south of the Serra do Curral, in the Quadrilatero Ferrffero, State of Minas Gerais (Fig. 1), has been considered by CARNEIRO (1990) as Archean in age. In this region occur several types of gneissic rocks and granitoid suites, as well as slightly metamorphosed or unmetamorphosed mafic dyke swarms intruding the Archean crust (Table 1). These mafic rocks have been previously divided into first and second generations by CARNEIRO (1990). New observations on field associations, petrography and, in particular, geochemical characteristics for these intrusive rocks allow a new division into three generations of amphibolitic rocks and one of diabasic rocks.

The first generation amphibolitic rocks are directly associated with the "Ancient gneiss" (Table 1) of the Bonfim Metamorphic Complex. These strongly foliated, melanocratic, amphibolitic rocks have granonematoblastic texture, with anhedral and polygonal crystals with triple junctions of mainly brownish-green hornblende, clouded plagioclase, and rare quartz, distributed in alternating layers. Opaque minerals, generally as corroded, anhedral crystals, are surrounded by anhedral brown titanite. Apatite is a common accessory mineral, and zircon occurs more rarely. Plagioclase is frequently saussuritized, and hornblende is replaced by minerals of the chlorite and epidote groups. Pale brownish biotite grows over hornblende in shear zones.

The second generation amphibolites (belonging to the second generation as originally proposed by CARNEIRO, 1990; see Table 1)are directly associated with granitoids of tonalitic composition and are represented by dykes of varied width. These melanocratic rocks are equigranular with medium grain size; the texture is granonematoblastic characterized by alternating layers of

\footnotetext{
'Departamento de Geologia, Universidade Federal de Ouro Preto, Ouro Preto, MG, Brazil.
} 


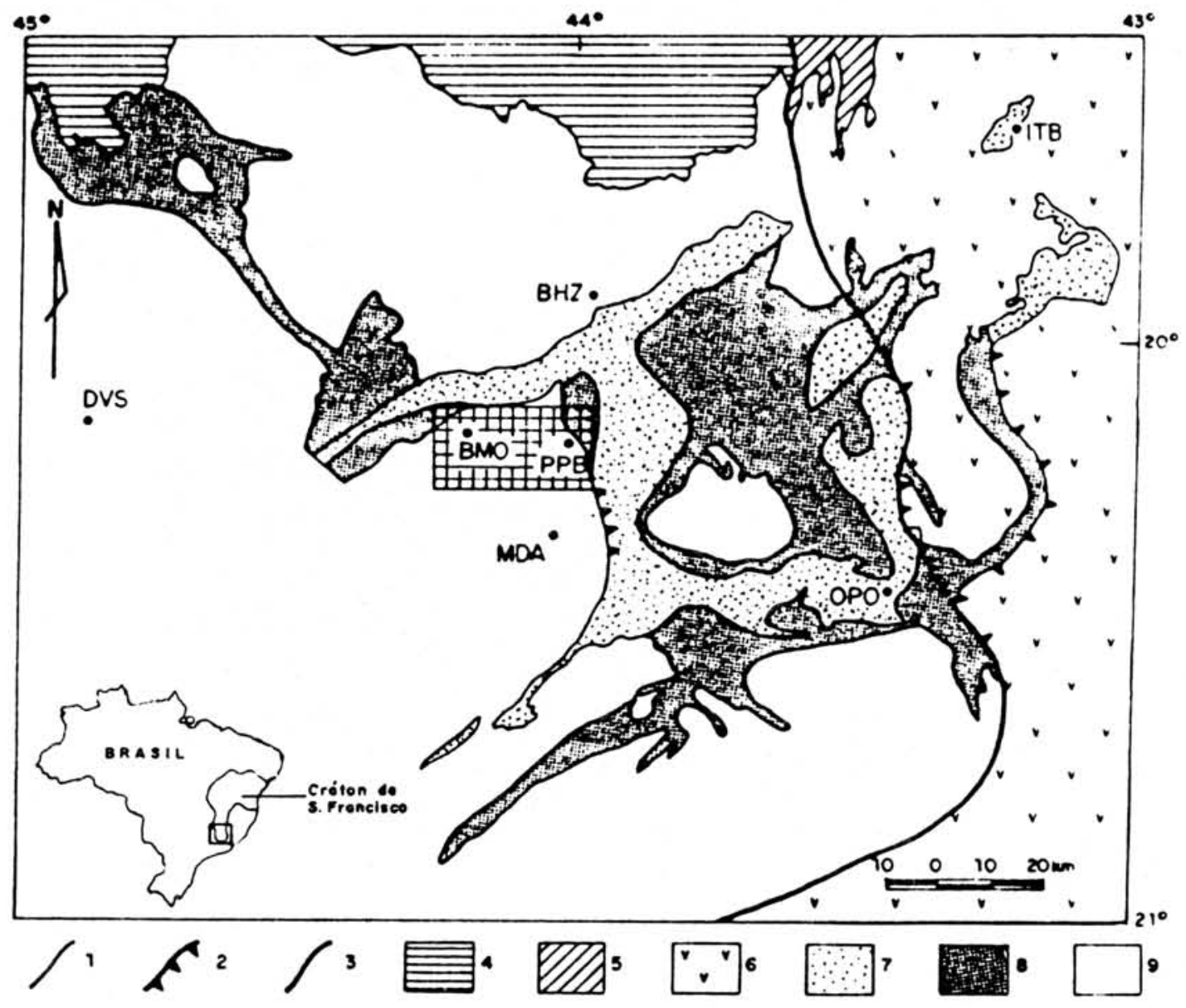

Figure 1 - Geology of the southern Săo Francisco Craton (modified from MARSHAK \& ALKMIN, 1989): 1 - Geologic contacts; 2 - Thrust faults; 3 - Craton limit; 4 -São Francisco Supergroup; 5 - Espinhaço Supergroup; 6 - Metamorphic Complex reworked during the Brasiliano event; 7 - Minas Supergroup; 8 - Rio das Velhas Supergroup; 9 - Metamorphic Complex reworked during the Transamazonico event. The northern sector of the Bonfim Metamorphic Complex is indicated by the cross-hatched pattern in the middle of the map. Cities: BHZ - Belo Horizonte; OPO - Ouro Preto; MDA - Moeda; PPB Piedade do Paraopeba; BMO - Brumadinho; DVS - Divinópolis; ITB - Itabira. 
Table 1 - Tentative stratigraphic sequence of the mafic intrusives in the northern Bonfim Metamorphic Complex (modified from CARNEIRO, 1990).

$\begin{array}{llll}\text { Herz (1970) } & \text { Carneiro (1990) } & \text { This paper } & \text { Age } \\ & & \text { Diabasic rocks } & \text { unknown } \\ & \begin{array}{l}\text { 3rd generation } \\ \text { amphibolites }\end{array} & \text { Proterozoic } \\ & \begin{array}{l}\text { 3rd generation } \\ \text { granitoids }\end{array} & \begin{array}{l}\text { 3rd generation } \\ \text { granitoids }\end{array} & \sim 2.7 \mathrm{Ga} \\ & \begin{array}{l}\text { 2nd generation } \\ \text { amphibolites }\end{array} & \begin{array}{l}\text { 2nd generation } \\ \text { amphibolites }\end{array} & <2.8 \mathrm{Ga} \\ & \begin{array}{l}\text { 2nd generation } \\ \text { granitoids }\end{array} & \begin{array}{l}\text { 2nd generation } \\ \text { granitoids }\end{array} & \sim 2.8 \mathrm{Ga} \\ \begin{array}{l}\text { 1st generation } \\ \text { granitoids } \\ \text { Souza Noschesse }\end{array} & \begin{array}{l}\text { 1st generation } \\ \text { granitoids }\end{array} & >2.7 \mathrm{Ga} \\ & \begin{array}{l}\text { 1st generation } \\ \text { amphibolites }\end{array} & \begin{array}{l}\text { 1st generation } \\ \text { amphibolites }\end{array} & \text { Archean } \\ \text { Ancient gneiss } & \text { Ancient gneiss } & >3.2 \mathrm{Ga} \\ \begin{array}{l}\text { Alberto Flores } \\ \text { granite (?) }\end{array} & & \end{array}$

anhedral and polygonal crystals with triple junctions mainly of pale green hornblende and clouded plagioclase. Hornblende forms aggregates of small anhedral crystals with a poikiloblastic-like texture, frequently containing small crystals of quartz and epidote, like "growth rings". Some of these rocks show large crystals of strongly saussuritized plagioclase (relict phenocrysts?). Small polygonal and anhedral crystals of quartz appear in the plagioclase-rich layers. Anhedral opaque minerals are commonly surrounded by anhedral brown titanite, which also occurs as long stringers in hornblenderich layers. Apatite is a common accessory mineral, and small crystals of zircon are rarely present.

The amphibolitic dykes of the third generation (metadiabase rocks) are intrusive into the Bonfim Complex and the Minas Supergroup. These rocks have intergranular relict texture with elongated and porphyritic crystals of saussuritized plagioclase and less frequent interstitial pyroxene (augite?), which is frequently replaced by an aggregate of green hornblende, epidote, titanite, brown biotite (within the hornblende) and, rarely, opaque minerals. Quartz appears as rare interstitial grains. Anhedral and corroded opaque minerals are surrounded by anhedral titanite. Apatite is a common accessory mineral.

The fourth generation dykes are diabasic rocks characterized by 
intergranular/ophitic texture, with subhedral and less frequently euhedral elongated crystals of clear plagioclase and less interstitial pyroxene (augite?). Pyroxene can be replaced by green hornblende and rarely by brown biotite (corona texture?). Rare quartz appears as interstitial anhedral crystals. Anhedral opaque minerals are frequently corroded and surrounded by titanite. Apatite is the most common accessory mineral.

The whole-rock geochemistry of the first and second generation amphibolites are similar, but very different from the third generation amphibolitic rocks. Overall, these geochemical data indicate that the these generations of metamorphosed mafic rocks are derived from tholeiitic magmas of continental affinity and can be classified according to R1xR2 cationic parameters (De La ROCHE et al., 1980; BELLENI et al., 1981) as follows: 1st generation - tholeiitic and transitional basalts; 2nd generation - tholeiitic, andesi- and latibasalts; 3rd generation - tholeiitic and lati-basalts, mugearites, latites and lati-andesites.

\section{REFERENCES}

BEШENI, G.; PICCIRILLO, E.M.; ZANETTIN, B. (1981) Classification and nomenclature of basalts. In: IUGS Subcommission on the Systematics of Igneous Rocks, Cambridge, CIRCULAR 34, Contribution 87:1-19.

CARNEIRO, M.A. (1990) Aspectos litoestratigráficos preliminares da Porção Setentrional do Complexo Metamórfico do Bonfim, Quadrilátero Ferrifero, Minas Gerais. In: CONGRESSO BRASILEIRO DE GEOLOGIA, 36., Natal, 1990. Boletim de Resumos. Natal, SBG. p.342.

De La ROCHE, H.; LETERRIER, J.; GRANDCLAUDE, P.; MARACHAL, M. (1980) A classification of volcanic and plutonic rocks using $R_{1}-R_{2}$ diagram and major-element analyses. Its relationships with current nomenclature. Chemical Geology, 29:183-210.

HERZ, N. (1970) Gneissic and igneous rocks of the Quadrilatero Ferrffero, Minas Gerais, Brazil. U.S.Geological Survey Professional Paper, 641B:1-58.

MARSHAK, S. \& ALKMIN, F.F. (1989) Proterozoic contraction/extension tectonics of the southern São Francisco region, Minas Gerais, Brazil. Tectonics, 8(3):555-571. 